\title{
Financial inclusion and their role in renewable energy and non-renewable energy consumption in China: Exploring the transmission channels
}

\section{Yukun Li}

King Mongkut's Institute of Technology Ladkrabang

Jian Chen

King Mongkut's Institute of Technology Ladkrabang

Muhammad Tayyab Sohail ( $\square$ tayyabsohail@yahoo.com )

Xiangtan University School of Public Administration https://orcid.org/0000-0002-7308-0297

\section{Research Article}

Keywords: Financial inclusion. Education. Energy consumption. China

Posted Date: March 8th, 2022

DOI: https://doi.org/10.21203/rs.3.rs-1355688/v1

License: (c) (i) This work is licensed under a Creative Commons Attribution 4.0 International License.

Read Full License 


\section{Abstract}

China is the most polluted economy in the world, facing the challenges of increased $\mathrm{CO} 2$ emissions. In this way, energy consumption is a key factor in $\mathrm{CO} 2$ emissions. To this end, this study empirically examines the effects of financial inclusion and education on energy consumption employing the ARDL approach for China during the period 1995-2019. The results suggest that financial inclusion has a positive effect on renewable energy consumption, but a negative impact on renewable energy and total energy consumption. The results show that education reduces non-renewable consumption and increases renewable energy consumption in the long-term. Long-run and short-run findings are also consistent and robust in the sensitivity analysis. Based on findings, China should invest in the education sector and increase financial inclusion to reduce energy consumption to meet environmental sustainability.

\section{Introduction}

Global warming is basically a result of enormous carbon secretions in the ecosystem as a result of largescale human activities to develop society economically and socially (Barro, 1996). It happens due to considerable dependence on the usage of non-renewable fuels (oil, coal, and natural gas) by nations all around the world for their mechanization efforts, urbanization, and demographic burdens. In the situation of absence of global harmony to pledge to the adaptation and moderation approaches by industrialized and emerging economies to steady the greenhouse gas effects due to carbon discharges and handle the unfriendly environmental filths and climate deviations underneath a mutual international agenda. The administrations of different nations in their own capabilities are making their progress and exerting energies to alleviate and shrink the menace of global heating, thus curtailing the natural susceptibilities linked with recurrent natural calamities (Marshall and Marshall, 1920). In order to accomplish such objectives, the nations are more determinedly accepting new environmental tactics and setting up monitoring rules for altering their scheme of energy consumption and trusting more on clean and green energy sources as compared to traditional energy sources and aiming to be more accommodating with sustainable environmental ethics by means of more sophisticated technologies in their manufacturing and consumption process. Among numerous policy schemes that the nations are implementing, the most effective one is to take environmental awareness among people of the society and it can be attainable by educating the people on the harmful effects of global warming. Moreover, social rules and ethical preaching are important tools that can guide the people to a substantial degree for improved ecological balance from its further worsening (Gylfason, 2001).

Though social preaching and developing ethical rules are important to limit environmental degradation further. However, the role of higher education is not only imperative for the process of wealth creation of a nation but also for specific sections of the economy. For instance, the energy sector is one of the several ways by means of which higher education plays a vital role in the development of the economy. With the evolution of higher education institutions more and more local and international students are attracted to these institutes which require more educational infrastructure and, push the energy demand further 
(Gossling, 2002 and Becken et al. 2003). Moreover, as the number of students, local and international, increase along with the total number of educational institutions energy demand will rise due to increased business and economic activities such as more hotels and hostel will develop, more transportation facilities, saloons, and dry cleaning services, etc. will be required. Consequently, though higher education expansion benefits the whole economy through various segments, it also contributes to a longstanding increase in energy demand. This points out the significance of implementing effective energy management strategies in order to attain energy preservation and environmental security. Augmented energy demand will increase in energy expenses by homes and businesses, which as a result will lead to an upsurge in the total income of the nation (Katircioglu, 2014). Hence, researchers need to pay more attention to the association between educational progress and energy consumption

In the conceptual framework, knowledge can affect energy consumption in two different ways i.e. the income and technology effects. The endogenous growth concept suggests that amassing of knowledge or education serves as a catalyst in aiding maintainable economic growth (Benos and Zotou, 2014). Though the findings from the energy-growth literature are inconclusive, sufficient empirical proof has recommended a positive linkage between energy demand and economic growth in several countries (Ozturk, 2010). In this backdrop, rising energy demand may have been pushed by rising income and the rise in income is a result of heavy investment in human capital or in other words education. On the other hand, it is significant to mention that knowledge buildup also allows swapping to technology that is much more energy-efficient, plummeting energy demand in the course (Li and Lin, 2016). Apart from the above-mentioned two effects, the third channel is the production function through which knowledge can affect the energy consumption if the link between physical assets, knowledge, and energy inputs is established (Salim et al., 2014 and Pablo-Romero and Sánchez-Braza, 2015). Precisely, if both human capital and energy inputs are interchangeable in the process of manufacturing, then human-capital amassing successfully decreases energy demand, while keeping the whole output static (Arbex and Perobelli, 2010).

Financial inclusion enhanced human welfare and reduced the poverty level but it also has a favorable impact on energy consumption (Bukari and Koomson, 2020 and Dogan et al. 2021). Financial inclusion enhances household and individuals welfare through the household facilitation for efficiency gains, household enterprises, health, and education (Stein and Yannelis, 2020). Financial inclusion affects energy consumption levels through household incomes, health, education, inequality, economic growth, labor efficiency, and energy efficiency. Financial inclusion enhances the level of income that directly influences the consumption level of households (Demirguc-Kunt et al., 2017). The study done by Sadath and Acharya (2017) denotes that financial inclusion affects energy poverty through changing the income level of households, inequality, and poverty. Financial inclusion enables individuals to securely and effectively perform financial transactions. An increase in financial inclusion and credit facilities can facilitate the household for investing in microenterprises, health, and education that increase occupational and labor incomes in the long-run (Kuada, 2019). 
The developments in labor incomes, health, and education due to financial inclusion may enhance occupational incomes that enable households to afford energy services. Financial inclusion enhances economic growth through mobilization of investment and savings in the product segment and decreasing transaction expenses, contracting, and information across the economy that results in efficiency gains which significantly influences income levels of poor households (Sharma, 2016). Financial inclusion influences the energy consumption level through the channel of economic growth. Financial inclusion stimulates energy efficiency through market development and financing for scalable and affordable clean energy products specifically for household purposes in developing economies (Boutabba et al., 2020). Access to modern and clean energy sources through financial inclusion promotes the efficiency of renewable and non-renewable energy consumption (Koomson \& Danquah, 2021).

China's remarkable growth over the preceding three decades was escorted by enormous upsurges in energy consumption. Certainly, since 2009 China has substituted the USA as the world's principal energy demander. In 2014 China used 4,260 million tons of typical coal equivalent energy. Hence, recognizing the elements behind China's unsaturated energy demand is ideal to predict its energy requirement and energy safety in the forthcoming (Lei et al. 2021). To date, a number of studies are available with regards to energy demand in China, and the majority of them aimed to find the impact of energy demand on economic growth (Yuan et al., 2008 and Bloch et al., 2015). Despite its catalytic part in encouraging economic growth, only a few researchers have scrutinized the influence of human capital, knowledge, or education on energy demand in the existing literature. According to Pachauri and Jiang (2008), the more educated the people of the society will be, the more will be the demand for energy-efficient electric appliances. Similarly, Broadstock et al. (2016) observed that more education will lead to less energy consumption due to more emphasis on energy efficiency.

Against this backdrop, we have asked a very pertinent question with regards to energy consumption in China: Does education really affect the consumption of energy in China?. Does financial inclusion cause energy consumption? Then, we also want to see whether the higher level of education really pushes the people towards more energy-efficient products or otherwise. The selection of China is not random, rather based on the fact that it is the largest consumer of energy in the world, hence, it can serve as an ideal country for examining the knowledge-energy nexus. Therefore, this study is a novel from three different aspects. To our knowledge, no study is available in the existing literature that has given special attention to a country like China with regards to the financial inclusion and education-energy consumption nexus. Last but not the least, this analysis is based on time series data which is free from any sort of aggregation bias.

In this study, we will see various sections. The second section consists of the econometric model and the technique we apply to get the estimates. In the third section, the findings of the study are discussed in detail. Lastly, we conclude our study in section five.

\section{Model And Methods}


The literature suggests that the key determinants of energy consumption are financial inclusion, education, internet users, economic development. In this empirical study we need to analyze the financial inclusion, education, and energy consumption nexus and constructed the following model:

$$
\mathrm{EC}_{\mathrm{t}}=\alpha_{0}+\alpha_{1} \mathrm{FI}_{\mathrm{t}}+\alpha_{2} \text { Education }_{\mathrm{t}}+\alpha_{3} \text { Internet }_{\mathrm{t}}+\alpha_{4} \mathrm{GDP}_{\mathrm{t}}+\mu_{\mathrm{t}}--(1)
$$

In the above model (3), energy consumption (EC) is reserved as the dependent variable and used as a vector of non-renewable, renewable, and overall energy consumption. Among the independent variables, financial inclusion (FI) and education are incorporated as main variables, but internet users (internet) and GDP per capita (GDP) are our control variables in the model. Financial inclusion helps to reduce energy poverty and boost energy consumption. In line with expectations, financial inclusion will be positive. As per our expectations because the development of education leads to a more cautious approach about the use of energy, thus helping in achieving high energy efficiency and signs will be negative. The basic model has presented only long-run parameter estimates. We prolong our basic model into an errorcorrection format by obtaining short-run parameter estimates as follows:

$$
\begin{aligned}
& \Delta \mathrm{EC}_{\mathrm{t}}=\gamma+\sum_{\mathrm{p}=1}^{\mathrm{n} 1} \gamma_{1 \mathrm{p}} \Delta \mathrm{EC}_{\mathrm{t}-\mathrm{p}}+\sum_{\mathrm{p}=0}^{\mathrm{n} 2} \gamma_{2 \mathrm{p}} \Delta \mathrm{FI}_{\mathrm{t}-\mathrm{p}}+\sum_{\mathrm{p}=0}^{\mathrm{n} 3} \gamma_{3 \mathrm{p}} \Delta \text { Education }_{\mathrm{t}-\mathrm{p}}+\sum_{\mathrm{p}=0}^{\mathrm{n} 4} \gamma_{4 \mathrm{p}} \Delta \text { Internet }_{\mathrm{t}-\mathrm{p}}+ \\
& \sum_{\mathrm{p}=0}^{\mathrm{n} 4} \gamma_{4 \mathrm{p}} \Delta \mathrm{GDP}_{\mathrm{t}-\mathrm{p}}+\pi_{1} \mathrm{EC}_{\mathrm{t}-1}+\pi_{2} \mathrm{FI}_{\mathrm{t}-1}+\pi_{3} \text { Education }_{\mathrm{t}-1}+\pi_{4} \text { Internet }_{\mathrm{t}-1}+\pi_{5} \mathrm{GDP}_{\mathrm{t}-1}+\mu_{\mathrm{t}}
\end{aligned}
$$

Specification (2) includes both long-run (one-period-lagged level) and short-run (first-differenced) variables. As noted by Ullah et al. (2021), the ARDL "bounds testing" method has been a number of smart features for time-series research work. This joint test is an F-test on the equation's long-run coefficients.

The null hypothesis in the equation is $\mathrm{HO}: \Pi_{1}=\Pi_{2}=\Pi_{3}=\Pi_{4}=\Pi_{5}=0$. This infers the non-existence of cointegration, but the alternative is $\mathrm{H} 1: \Pi_{1} \neq 0, \Pi_{2} \neq 0, \Pi_{3} \neq 0, \Pi_{4} \neq 0, \Pi_{5} \neq 0$. In short, Pesaran et al. (2001) provide a new set of critical values for the F-test. If ECM coefficient estimates are negative and significantly negative, thus we can say that cointegration is present. ARDL cointegration approach is preferable in a mixed order of integration. Another benefit of ARDL is that it is better performed in a small sample size of data, as in our study. The sample size of the dataset is 25 years for the Chinese economy. ARDL procedure offers short and long-run estimates in a single step. We also confirmed some diagnostic statistics in the end, such as Lagrange Multiplier (LM) test for autocorrelation, Breusch-Pagan (BP) test for heteroskedasticity, Ramsey RESET test for functional misspecification, and CUSUM and CUSUM-Sq tests for model stability. In end, short and long-run results are reported in detail in the next section.

\section{Data}

The purpose of this empirical study is to see the effect of financial inclusion and education on the energy consumption of China. For analysis, we used the annual data of China from 1995 to 2019 because China is the largest consumer of energy in the world. The dependent variable is the consumption of nonrenewable, renewable, and total energy consumption (quad BTU). The independent variable is financial inclusion and education, while control variables are GDP per capita, energy price, and capital stock. We acquire the dataset from IMF, IEA, Barro and Lee, and World Bank. We obtained energy-related data from 
Energy Information Administration (IEA), financial inclusion offered by IMF, and education data given by Barro and Lee. We acquire the data on all control variables from the World Bank. Table 1 provides the variables definitions and descriptive statistics.

Table 1

Variables definition and description

\begin{tabular}{|c|c|c|c|c|c|c|}
\hline Variables & Symbol & Definitions & Mean & Max & Min & $\begin{array}{l}\text { Std. } \\
\text { Dev. }\end{array}$ \\
\hline \multirow{2}{*}{$\begin{array}{l}\text { Non-renewable } \\
\text { energy } \\
\text { consumption }\end{array}$} & NRE & $\begin{array}{l}\text { Non-renewable energy is } \\
\text { measured in quad BTU }\end{array}$ & 4.366 & 4.994 & 3.618 & 0.526 \\
\hline & & $\begin{array}{l}\text { from the sum of natural gas, } \\
\text { coal, and petrol }\end{array}$ & & & & \\
\hline \multirow{3}{*}{$\begin{array}{l}\text { Renewable } \\
\text { energy } \\
\text { consumption }\end{array}$} & RE & $\begin{array}{l}\text { Renewable energy is measured } \\
\text { in quad BTU }\end{array}$ & 1.570 & 2.797 & 0.521 & 0.811 \\
\hline & & from the sum of wind energy, & & & & \\
\hline & & $\begin{array}{l}\text { nuclear energy, solar energy, } \\
\text { and biofuel energy }\end{array}$ & & & & \\
\hline $\begin{array}{l}\text { Total energy } \\
\text { consumption }\end{array}$ & TE & $\begin{array}{l}\text { Sum of non-renewable energy } \\
\text { consumption and renewable } \\
\text { energy consumption }\end{array}$ & 4.428 & 5.100 & 3.663 & 0.543 \\
\hline $\begin{array}{l}\text { Year of } \\
\text { schooling }\end{array}$ & Education & Average year of schooling & 11.70 & 14.60 & 9.100 & 1.928 \\
\hline Bank branches & BB & $\begin{array}{l}\text { Bank branches per 100,000 } \\
\text { adults }\end{array}$ & 6.337 & 9.409 & 3.266 & 1.885 \\
\hline ATMs & ATMS & ATMs per 100,000 adults & 29.09 & 91.36 & 1.033 & 31.65 \\
\hline Internet users & Internet & $\begin{array}{l}\text { Individuals using the Internet } \\
\text { (\% of population) }\end{array}$ & 24.00 & 64.56 & 0.005 & 22.64 \\
\hline GDP per capita & GDP & $\begin{array}{l}\text { GDP per capita (constant } 2010 \\
\text { US\$) }\end{array}$ & 15.33 & 16.83 & 13.19 & 1.027 \\
\hline
\end{tabular}

\section{Results And Discussion}

The first step in the result section is to determine, the integrating properties of the variables and to check that none is integrated at the second-order i.e. I (2). To that end, we have applied two types of unit root tests; without breakpoint and with the breakpoint. The results of both types of tests are provided in Table 2 , confirming the fact that variables are either I (0) or I (1) which ratifies the application of the bounds testing approach. The dynamic behavior of the variables is based on the number of lags included in the model and the frequency of our data is annual, hence, we have included two lags maximum and for selecting the optimal lags Akaike Information Criterion is applied. 
Table 2

Unit root testing

\begin{tabular}{|c|c|c|c|c|c|c|c|c|}
\hline & \multicolumn{3}{|c|}{ Unit root without a break } & \multicolumn{5}{|c|}{ Unit root without a break } \\
\hline & $\mathrm{I}(0)$ & $\mathrm{I}(1)$ & Decision & $\mathrm{I}(0)$ & $\begin{array}{l}\text { Break } \\
\text { date }\end{array}$ & $\mathrm{I}(1)$ & $\begin{array}{l}\text { Break } \\
\text { date }\end{array}$ & Decision \\
\hline NRE & -0.265 & $-3.284^{\star \star}$ & $\mathrm{I}(1)$ & 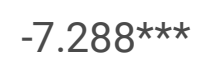 & 2002 & & & $\mathrm{I}(0)$ \\
\hline RE & -0.116 & $-4.532^{\star \star \star}$ & $\mathrm{I}(1)$ & -2.612 & 2003 & $-5.956 * \star \star$ & 2018 & $\mathrm{I}(1)$ \\
\hline TE & -0.226 & $-3.173^{\star \star}$ & $\mathrm{I}(1)$ & $-6.287 * \star \star$ & 2002 & & & $\mathrm{I}(0)$ \\
\hline Education & -0.216 & $-6.558 * \star \star$ & $\mathrm{I}(1)$ & -0.868 & 1996 & $-6.677 * \star \star$ & 2017 & $\mathrm{I}(1)$ \\
\hline BB & 0.321 & $-4.012^{\star \star \star}$ & $\mathrm{I}(1)$ & -0.152 & 2001 & $-14.12^{\star \star \star}$ & 2014 & $\mathrm{I}(1)$ \\
\hline ATMs & 1.203 & $-2.754^{\star}$ & $\mathrm{I}(1)$ & -1.635 & 2009 & $-4.322 *$ & 2009 & $\mathrm{I}(1)$ \\
\hline GDP & -0.716 & $-2.701^{\star}$ & $\mathrm{I}(1)$ & -1.798 & 2001 & $-4.989 * \star \star$ & 2007 & $\mathrm{I}(1)$ \\
\hline Internet & 0.123 & $-2.652^{\star}$ & $\mathrm{I}(0)$ & -2.478 & 2007 & $-4.325^{\star}$ & 2006 & $\mathrm{I}(1)$ \\
\hline
\end{tabular}

The estimates of the linear ARDL models are presented in Table 3. The main findings show that education has significantly and positively impacted NRE consumption in the long run, though, the impact in the short run appears also significant. This result is as per expectations and complements the findings of Pata and Caglar (2020), Salim et al. (2016), Yao et al. (2019). The result suggests that a $1 \%$ rise in education in China reduces the non-renewable energy consumption by $0.442 \%$. In simple words, our findings confirm that the usage of human capital, as an input, has substituted the NRE in the production function (Yang et al. 2017). The estimates attached to education are positive and significant in the renewable energy model in the long run and, in the short run, the result is vice versa. In long run, a 1\% increase in education increases the consumption of renewable energy by $0.453 \%$ implying the fact that development in human capital has helped the production process in China to be shifted from NRE to RE consumption. Moreover, the higher level of education makes the people more conscious about the environment; hence, they use energy more efficiently and replace the NRE with RE (Zou et al., 2016; Li and Lin, 2016). Our findings are in line with the previous studies of Salim et al. (2016) for China, Yao et al. (2019) for selected OECD countries, Akram et al. (2018) for India, and Shahbaz et al. (2019) for the USA. Finally, the estimated coefficient of education in the TE model is insignificant both in the long run suggesting the fact that positive impact in RE model and negative impact in NRE model might cancel out each other, and overall impact might have become insignificant. The general meaning of these findings is that the rise in education reduces the use of NRE and increases the use of RE meaning that investors in China are more responsible and observe pro-environmental practices. The results of the NRE and TE models are as per our expectations because the development of human capital leads to a more cautious approach to the use of energy and its harmful impact on the environment, thus helping in achieving high energy efficiency (Vidotto et al. 2017). 
In long run, the estimated coefficients of ATMs are significant and negative in non-renewable energy and total energy models. Numerically, a $1 \%$ rise in ATMs significantly reduces the use of non-renewable energy consumption by $0.002 \%$ and total energy consumption by $0.002 \%$. On the other side, the estimated attached ATMs is significant and positive in the renewable energy model and the size of the estimate is 0.004 , respectively. These findings imply that a $1 \%$ rise in ATMs decreases renewable energy consumption by $0.004 \%$. The short-run ATMs results have the same interpretation as explained in the long-run. These findings are backed by Koomson and Danquah (2021), who noted that financial inclusion decreases household energy poverty by improving education, health, income, and energy efficiency. The possible inference is that financial inclusion provides the resources needed by households to access clean fuels and technologies. Financial inclusion helps to smooth households' consumption of modern and clean energy. These results are reliable with existing studies that financial inclusion significantly enhances green economic efficiency (Boutabba et al., 2020 Wang et al. 2022). A similar finding is also reported by Shahbaz et al. (2022), who infers that financial inclusion increases the consumption of renewable energy in China.

The estimated coefficients of the internet appeared to be negative significant in almost all the models in the short run. In long run, the internet has exerted a negative and significant impact on NRE, RE and TE consumption. More specifically, we can say that a $1 \%$ rise in the internet of China increases the use of non-renewable energy by $0.010 \%$, renewable energy by $0.006 \%$, and total energy by $0.011 \%$. The size of the estimate is large in the non-renewable energy model as compared to the renewable energy model which indicates China's reliance on energy sources based on fossil fuels for its growth scheme in the digital era. Besides, due to rising digital inclusion, policy-makers are also focusing more on renewable energy and advancement in human capital promotes innovations that help in developing more assets related to clean energy (Usman et al. 2021 and Ullah et al. 2021). However, one surprising result is the reduction in the use of renewable energy and the implied reason could be the inaccessibility and unaffordability of such sources of energy. These findings imply that increased use of overall energy consumption is positively linked with GDP in China's in short. However, GDP does not influence NRE, RE, and TE consumption in China in long-run.

These long-run results are valid relying on the calculated values, presented under diagnostics in Table 3, either F-test or ECM (-1). Some other diagnostic tests are also reported such as Langrage Multiplier (LM) for first-order serial correlation, Ramsey RESET for misspecification, Breusch-Pagan-Godfrey (BPG) for heteroscedasticity, and CUSUM \& CUSUM-sq tests for parametric stability. From the diagnostic statistics, we gather that most of our models are free from these complications. The sensitivity checks are confirmed to test the variable-based robustness in Table 4. Long-run and short-run findings are also consistent and robust across variables based on sensitivity analysis. 
Table 3

Short and long-run estimates of ARDL

\begin{tabular}{|c|c|c|c|c|c|c|}
\hline & NRE & & RE & & TE & \\
\hline & Coefficient & t-Stat & Coefficient & t-Stat & Coefficient & t-Stat \\
\hline \multicolumn{7}{|l|}{ Short-run } \\
\hline EDUCATION & $0.303^{\star \star \star}$ & 3.722 & $0.498 * \star \star$ & 4.902 & $0.308^{\star * *}$ & 3.796 \\
\hline EDUCATION(-1) & -0.086 & 0.909 & $-0.472^{\star \star \star}$ & 3.917 & -0.121 & 1.354 \\
\hline EDUCATION(-2) & 0.230 ** & 2.803 & $0.913^{\star \star \star}$ & 9.546 & $0.275^{\star \star \star}$ & 3.479 \\
\hline ATMS & $-0.002^{*}$ & 1.909 & $0.007 * \star$ & 2.034 & $-0.002^{\star}$ & 1.773 \\
\hline ATMS(-1) & & & -0.004 & 1.022 & & \\
\hline ATMS(-2) & & & 0.005 & 1.454 & & \\
\hline INTERNET & $-0.032^{\star \star *}$ & 3.046 & $-0.037 * \star \star \star$ & 4.171 & $-0.032 * \star \star$ & 3.171 \\
\hline INTERNET(-1) & $0.021^{\star \star}$ & 2.459 & $0.025^{\star \star \star}$ & 2.629 & $0.021^{\star \star}$ & 2.465 \\
\hline GDP & -0.028 & 1.499 & -0.048 & 1.085 & $-0.031^{*}$ & 1.712 \\
\hline GDP(-1) & $0.026^{*}$ & 1.682 & 0.003 & 0.053 & $0.028^{*}$ & 1.904 \\
\hline GDP(-2) & & & $0.073^{\star \star}$ & 2.086 & & \\
\hline \multicolumn{7}{|l|}{ Long-run } \\
\hline EDUCATION & $-0.442^{\star \star \star}$ & 13.13 & $0.453^{\star \star \star}$ & 12.84 & 0.449 & 1.014 \\
\hline ATMS & $-0.002^{\star}$ & 1.718 & $0.004^{\star \star \star}$ & 5.000 & $-0.002^{\star}$ & 1.806 \\
\hline INTERNET & $-0.010 * * *$ & 2.928 & -0.006 ** & 1.999 & $-0.011 * \star \star$ & 3.235 \\
\hline GDP & -0.003 & 0.214 & 0.013 & 1.176 & -0.003 & 0.289 \\
\hline C & -0.365 & 0.919 & $-3.778 * \star \star$ & 8.972 & $-0.375^{\star}$ & 1.935 \\
\hline \multicolumn{7}{|l|}{ Diagnostics } \\
\hline F-test & 4.125 & & 8.542 & & 4.468 & \\
\hline $\operatorname{ECM}(-1)$ * & $-0.452^{\star \star \star}$ & 5.603 & $-0.473^{\star \star \star}$ & 16.26 & $-0.429 * * *$ & 6.162 \\
\hline LM & 1.023 & & 1.254 & & 1.157 & \\
\hline BP & 1.987 & & 0.365 & & 2.321 & \\
\hline RESET & 1.214 & & 0.801 & & 1.857 & \\
\hline
\end{tabular}

Note: ${ }^{* \star *} p<0.01 ;{ }^{* \star} p<0.05 ;{ }^{*} p<0.1$ 


\begin{tabular}{|llll|}
\hline & NRE & RE & TE \\
\hline CUSUM & S & S & S \\
\hline CUSUM-sq & S & $S$ & $S$ \\
\hline Note: $* * * p<0.01 ; * * p<0.05 ; * p<0.1$ & & \\
\hline
\end{tabular}


Table 4

Short and long-run estimates of ARDL (Robustness)

\begin{tabular}{|c|c|c|c|c|c|c|}
\hline & NRE & & RE & & TE & \\
\hline Variable & Coefficient & $\mathrm{t}-$ Stat & Coefficient & t-Stat & Coefficient & t-Stat \\
\hline \multicolumn{7}{|l|}{ Short-run } \\
\hline EDUCATION & $0.222^{\star \star}$ & 2.530 & 0.013 & 0.104 & $0.230 * \star \star$ & 2.643 \\
\hline EDUCATION(-1) & -0.272 ** & 2.372 & -0.146 & 0.964 & $-0.275^{\star \star}$ & 2.434 \\
\hline EDUCATION(-2) & $0.191^{* *}$ & 2.402 & $0.753^{\star \star \star}$ & 8.967 & 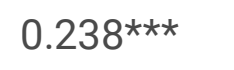 & 3.085 \\
\hline BB & $-0.068^{*}$ & 1.783 & $0.246^{\star \star}$ & 1.962 & $-0.066^{\star}$ & 1.890 \\
\hline $\mathrm{BB}(-1)$ & & & $-0.345^{\star \star}$ & 2.218 & & \\
\hline $\mathrm{BB}(-2)$ & & & 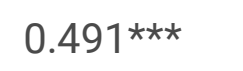 & 2.978 & & \\
\hline INTERNET & $-0.027 * \star \star *$ & 2.676 & $-0.016^{*}$ & 1.741 & $-0.028 * \star \star$ & 2.903 \\
\hline INTERNET(-1) & $0.041^{* * *}$ & 3.067 & -0.007 & 0.416 & $0.038 * \star \star *$ & 2.904 \\
\hline INTERNET(-2) & $-0.023^{* * *}$ & 2.676 & $0.024 * \star$ & 2.100 & $-0.020 \star *$ & 2.291 \\
\hline GDP & 0.011 & 0.007 & 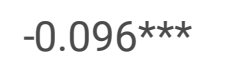 & 3.450 & -0.002 & 0.131 \\
\hline GDP(-1) & & & $0.043^{*}$ & 1.661 & & \\
\hline \multicolumn{7}{|l|}{ Long-run } \\
\hline EDUCATION & $0.372^{\star \star \star}$ & 2.859 & $0.272^{\star \star \star}$ & 7.501 & $0.412^{\star \star \star}$ & 5.227 \\
\hline BB & -0.180 & 0.732 & $0.179 * \star \star$ & 5.759 & -0.140 & 0.851 \\
\hline INTERNET & $-0.024^{\star}$ & 1.820 & $-0.005^{\star \star}$ & 2.115 & $-0.023^{*}$ & 1.927 \\
\hline GDP & 0.004 & 0.007 & -0.024 ** & 3.245 & -0.004 & 0.137 \\
\hline C & -0.514 & 0.486 & $-2.204 * \star \star$ & 6.578 & $-0.617^{\star}$ & 1.820 \\
\hline \multicolumn{7}{|l|}{ Diagnostics } \\
\hline F-test & 4.587 & & 9.254 & & 4.721 & \\
\hline $\operatorname{ECM}(-1)$ * & $-0.439 * \star \star$ & 4.994 & $-0.426 * \star \star \star$ & 16.48 & $-0.470 * \star \star$ & 5.437 \\
\hline LM & 1.254 & & 1.654 & & 1.355 & \\
\hline BP & 0.478 & & 1.95 & & 0.354 & \\
\hline RESET & 1.688 & & 1.245 & & 0.324 & \\
\hline
\end{tabular}

Note: ${ }^{* \star *} p<0.01 ;{ }^{* \star} p<0.05 ;{ }^{*} p<0.1$ 


\begin{tabular}{|llll|}
\hline & NRE & RE & TE \\
\hline CUSUM & S & S & S \\
\hline CUSUM-sq & S & S & S \\
\hline Note: ${ }^{* \star *} p<0.01 ; * * p<0.05 ; * p<0.1$ & & \\
\hline
\end{tabular}

\section{Conclusion And Implications}

Unlike previous limited literature, our study is adding to the current stock of literature by exploring the transmission channels and effects of financial inclusion and education on non-renewable energy consumption, renewable energy consumption, and total energy consumption for China, from 1995 to 2019. The long-run empirical findings of ARDL indicate that education negatively affects non-renewable energy consumption and positively affects renewable energy consumption; however, the effect of education on total energy consumption is statistically insignificant. However, the long-run empirical findings of ARDL demonstrate that financial inclusion negatively affects non-renewable energy consumption and total energy consumption, however, financial inclusion has a positive impact on renewable energy consumption in China. The short-run findings of ARDL indicate that education positively affects non-renewable energy, renewable energy, and total energy consumption. On the other hand, the short-run empirical findings reveal that financial inclusion negatively affects non-renewable energy and total energy consumption, but, education exerts a positive impact on renewable energy consumption.

From a policy point of view, it is normally acknowledged that the implementation of renewable energy is fundamental to diminish global warming and to alleviate carbon emissions (Haines et al., 2007). Clean energy plus clean environmental technologies policies should be adapted immediately at a national and provincial level in China. China should increase the consumption and production of renewable energy. Our main results for the influence of education on renewable energy consumption, non-renewable energy consumption and total energy consumption suggest that investment in education is a less distortionary and effective solution to overcome green growth and environmental challenges. The findings show that education exerts a significantly larger impact on the energy mix in the long-run as compared with the impact of short-run. This finding suggests that policymakers may get less incentive to promote education in the short-run since attaining environmental-related benefits from education is a long-run phenomenon. China should raise clean energy-related workshops at provincial and national levels. China can achieve energy consumption-related objectives with an effective education system. Finding also suggested that the important linkages of financial inclusion and energy consumption must be considered in the process of policymaking. The existing policies currently being used to increase financial inclusion and the other policies are determined to increase the income level of households and mitigate the level of energy poverty. Efforts are required at the government level to bring into line the targets of financial inclusion with environmental policies and energy consumption behavior. 
Future research should be more focused on analyzing financial inclusion and human capital and their impact on green growth. The current study is only conducted for the aggregate level of education, while further studies should be conducted at the dis-aggregate level of education on energy consumption and green growth. However, future studies could explore the effects and transmission channels nexus among financial inclusion, education, and energy poverty in the context of polluted economies.

\section{Declarations}

Ethical Approval: Not applicable

Consent to Participate: I am free to contact any of the people involved in the research to seek further clarification and information

Consent to Publish: Not applicable

Author's Contributions: This idea was given by Yukun Li. Yukun Li, and Jian Chen analyzed the data and wrote the complete paper. While Muhammad Tayyab Sohail read and approved the final version.

Funding: Not applicable

Competing Interests: The authors declare that they have no conflict of interest.

Availability of data and materials: The datasets used and/or analyzed during the current study are available from the corresponding author on reasonable request.

\section{References}

1. Ang JB, Madsen JB (2011) Can second-generation endogenous growth models explain the productivity trends and knowledge production in the Asian miracle economies? Rev Econ Stat 93(4):1360-1373

2. Arbex M, Perobelli FS (2010) Solow meets Leontief: Economic growth and energy consumption. Energy Econ 32(1):43-53

3. Becken S, Frampton C, Simmons D (2001) Energy consumption patterns in the accommodation sector-the New Zealand case. Ecol Econ 39(3):371-386

4. Becken S, Simmons DG, Frampton C (2003) Energy use associated with different travel choices. Tour Manag 24(3):267-277

5. Benos N, Zotou S (2014) Education and economic growth: A meta-regression analysis. World Dev 64:669-689

6. Bloch H, Rafiq S, Salim R (2015) Economic growth with coal, oil and renewable energy consumption in China: Prospects for fuel substitution. Econ Model 44:104-115 
7. Boutabba MA, Diaw D, Laré A, Lessoua A (2020) The impact of microfinance on energy access: a case study from peripheral districts of Lomé, Togo. Appl Econ 52(45):4927-4951

8. Broadstock DC, Li J, Zhang D (2016) Efficiency snakes and energy ladders: A (meta-) frontier demand analysis of electricity consumption efficiency in Chinese households. Energy Policy 91:383396

9. Dogan E, Madaleno M, Taskin D (2021) Which households are more energy vulnerable? Energy poverty and financial inclusion in Turkey. Energy Econ 99:105306

10. Gössling S (2002) Global environmental consequences of tourism. Glob Environ Change 12(4):283302

11. Katircioğlu ST (2014) Estimating higher education induced energy consumption: The case of Northern Cyprus. Energy 66:831-838

12. Koomson I, Danquah M (2021) Financial inclusion and energy poverty: Empirical evidence from Ghana. Energy Econ 94:105085

13. Kuada J (2019) Financial inclusion and the sustainable development goals. Extending Financial Inclusion in Africa. Academic Press, pp 259-277

14. Li K, Lin B (2016) Impact of energy technology patents in China: Evidence from a panel cointegration and error correction model. Energy Policy 89:214-223

15. Murad MW, Alam MM, Noman AHM, Ozturk I (2019) Dynamics of technological innovation, energy consumption, energy price and economic growth in Denmark. Environ Prog Sustain Energy 38(1):2229

16. Odgaard O, Delman J (2014) Chinal s energy security and its challenges towards 2035. Energy Policy 71:107-117

17. Ozturk I (2010) A literature survey on energy-growth nexus. Energy policy 38(1):340-349

18. Pablo-Romero MDP, Sánchez-Braza A (2015) Productive energy use and economic growth: Energy, physical and human capital relationships. Energy Econ 49:420-429

19. Pachauri S, Jiang L (2008) The household energy transition in India and China. Energy policy 36(11):4022-4035

20. Pata UK, Caglar AE (2021) Investigating the EKC hypothesis with renewable energy consumption, human capital, globalization and trade openness for China: Evidence from augmented ARDL approach with a structural break. Energy 216:119220

21. Sadath AC, Acharya RH (2017) Assessing the extent and intensity of energy poverty using Multidimensional Energy Poverty Index: Empirical evidence from households in India. Energy Policy 102:540-550

22. Salim RA, Rafiq S (2012) Why do some emerging economies proactively accelerate the adoption of renewable energy? Energy Econ 34(4):1051-1057

23. Salim R, Yao Y, Chen GS (2017) Does human capital matter for energy consumption in China? Energy Econ 67:49-59 
24. Shahbaz M, Gozgor G, Hammoudeh S (2019) Human capital and export diversification as new determinants of energy demand in the United States. Energy Econ 78:335-349

25. Sharma D (2016) Nexus between financial inclusion and economic growth: Evidence from the emerging Indian economy. J Financial Economic Policy 8(1):13-36

26. Stein LC, Yannelis C (2020) Financial inclusion, human capital, and wealth accumulation: Evidence from the freedman's savings bank. Rev Financial Stud 33(11):5333-5377

27. Vidotto JDF, Ferenhof HA, Selig PM, Bastos RC (2017) A human capital measurement scale.Journal of Intellectual Capital

28. Wang L, Wang Y, Sun Y, Han K, Chen Y (2022) Financial inclusion and green economic efficiency: evidence from China. J Environ Planning Manage 65(2):240-271

29. Yao Y, Ivanovski K, Inekwe J, Smyth R (2019) Human capital and energy consumption: Evidence from OECD countries. Energy Econ 84:104534

30. Yuan JH, Kang JG, Zhao CH, Hu ZG (2008) Energy consumption and economic growth: evidence from China at both aggregated and disaggregated levels. Energy Econ 30(6):3077-3094 